\title{
EFFECT OF GLUTEN -FREE COMPOSITE FLOUR ON THE QUALITY PROPERTIES OF CUPCAKE
}

\author{
A. A. A. Hassan, E. A. Elbarkoli, A. H. Khalil, E. H. Mansour \\ and A. A. El-Bedawey \\ Food Science and Technology Department, Faculty of Agriculture, Menoufia University, Shibin \\ El-Kom, Egypt
}

Received: Aug. 8, 2017

Accepted: Aug. 20, 2017

\begin{abstract}
Composite flours were formulated from 53.5-54.5\% rice flour, $25 \%$ corn starch, $10 \%$ chickpea flour and 10\% defatted soy bean flour with 1\% carboxy methyl cellulose (CMC), or $1.5 \%$ CMC or 0.25 xanthan $+0.25 \%$ CMC or $0.25 \%$ guar gum +0.25 CMC. Batter properties and cupcake quality of wheat flour and composite flours were evaluated. Mixolab profile, Mixolab simulator mode, chemical composition, physical properties, crust color, crumb color, alkaline water retention capacity and sensory properties of cupcakes were evaluated. Composite flours had higher water absorption and dough stability than control flour. Dough development time and dough weakening values of composite flour were so close to wheat flour. The $C 1$ and $C 2$ values were not affected by replacing wheat flour with composite flours. The $C 3$, $\mathrm{C} 4$ and $\mathrm{C} 5$ values of wheat flour were higher than composite flours. Composite flour cupcakes had higher crude protein and total ash contents and lower carbohydrates content than control cupcake. Weight of all cupcakes did not differ. Specific volumes and height of composite flour cupcakes containing 1 and 1.5\% CMC were higher than control cupcake and other composite flour cupcakes. Composite flour cupcakes had lighter crust color than control cupcake. Composite flour cupcake containing 1.5\% CMC had the darker crumb color among all cupcakes. The other composite flour cupcakes had lighter crumb color than the control cupcake. Composite flour cupcakes had lower alkaline water retention capacity than control cupcake. Alkaline water retention capacity of cupcakes was decreased by increasing storage period. Overall acceptability of control cupcake had rating score described as like extremely. Composite flour cupcakes containing 1.5\% CMC, 0.25 xanthan $+0.25 \%$ CMC and $0.25 \%$ guar gum $+0.25 \mathrm{CMC}$ had rating score described as like very much. The produced cupcake from gluten free flour was as good as the wheat product.
\end{abstract}

Key words: Mixolab profile, Mixolab simulator mode, Crust and crumb color, Alkaline water retention capacity and sensory properties.

\section{INTRODUCTION}

Wheat is an important part of the daily diet of peoples. The gluten fraction was reported to be responsible for coeliac disease and later on food allergy (Larré et al., 2011). It may be defined as an inflammatory disease of the small intestine triggered by the storage (gluten) proteins not only from wheat but also from rye, barley and possibly, oats (Gessendorfer et al., 2010). An immune reaction in the small intestine damages the mature absorptive epithelial cells and results in diarrhoea, abdominal pain, and growth disorders
(Gallagher et al., 2004 and Moore et al., 2006). The need for gluten-free products is increasing since the prevalence of celiac disease has increased over time (Lohi, et. al., 2007).

Since the diet of Celiac patients must be completely free from any gluten, so all the products from wheat, rye, barley and oat must be replaced with gluten free flours such as rice flour, corn flour, sorghum flour corn starch, potato starch, and pseudo cereals or appropriate mixtures (AlvarezJubete, et.al. 2010, Ranjbar et al., 2012 and Hussein et al., 2012). Legumes and oilseed 
proteins were used for fortification of bakery products by improving their protein quality, mechanical behavior and storage life (Sanchez et al., 2004 and Hegazy et al., 2009). Hydrocolloids (pectin, hydroxyl propylmethyl cellulose, carboxy methyl cellulose, guar gum, xanthan gum, and locust bean gum) are added to naturally gluten-free flours to mimic the viscoelastic properties of gluten and to improve structure, sensory attributes and shelf-life of these products (Kotoki and Deka, 2010 and Correa, et.al. 2010 ).

When gluten-free flour is mixed to form dough, it does not form a continuous phase or dough structure and consequently fails to produce good quality bread (Ranhotra et al, 1975). Therefore, this study was aimed to evaluate the Influence of gluten-free flours (rice flour, corn starch, defatted soybean flour and chickpea flour) and hydrocolloids (1\% CMC, $1.5 \%$ CMC, $0.25 \%$ xanthan gum $+0.25 \% \mathrm{CMC}$ and $0.25 \%$ gar gum $+0.25 \%$ $\mathrm{CMC}$ ) on the quality properties of cupcake.

\section{MATERIALS AND METHODS Materials:}

Wheat flour for cake (72\% extraction), was obtained from the Five star flour Mills Company, Giza, Egypt. Chickpea (Giza, 195), rice (Giza, 151) seeds and defatted soybean flour were obtained from Agricultural Research Center, Ministry of Agriculture, Giza, Egypt. Corn starch, compressed yeast, skim dry milk, sugar, corn oil, vanilla and baking powder were obtained from local market Giza, Egypt.
Composite flours were formulated as shown in Table (I).

\section{Methods: \\ Preparation of cupcake:}

Cupcake was prepared according to Khalil (1998) using the following recipe, $760 \mathrm{~g}$ soft wheat flour (72\% extraction), $380 \mathrm{~g}$ sugar, $380 \mathrm{~g}$ corn oil, $380 \mathrm{~g}$ fresh whole egg, $26.6 \mathrm{~g}$ skim dry milk, $22.8 \mathrm{~g}$ baking powder and $1.0 \mathrm{~g}$ vanilla. To prepare the control cupcake, the sugar and corn oil were creamed for $3 \mathrm{~min}$ at speed 5 in an Oster Kitchen Center mixer (Model 972-26 H, Sunbeam Corporation, Milwaukee, Wisconsin, USA). The whole eggs were added and mixed in at the same speed for 2 min. The flour and baking powder were added and the batter was mixed for $4 \mathrm{~min}$ at speed 6 . After scraping down the bowl the batter was mixed for an additional $1 \mathrm{~min}$ at speed 6 . To prepare the composite flour cupcakes, the wheat flour in the formula was replaced by composite flours (Table I). The same order of mixing as described for the control was followed. Cake batter $(50 \mathrm{~g})$ was poured into paper baking cups. Cupcake batters were baked at $180^{\circ} \mathrm{C}$ for $45 \mathrm{~min}$. After $5 \mathrm{~min}$, the cakes were removed from the pans and cooled for $60 \mathrm{~min}$.

\section{Proximate composition}

Moisture, crude protein, crude fat and total ash for cupcake were determined according to the methods described in AOAC (2005). Total carbohydrates were calculated by difference.

\section{Formulation of composite flours}

Table (I): Formulation of composite flours

\begin{tabular}{|l|c|c|c|c|c|c|c|}
\hline & $\begin{array}{c}\text { Rice flour } \\
(\%)\end{array}$ & $\begin{array}{c}\text { Corn starch } \\
(\%)\end{array}$ & $\begin{array}{c}\text { Defatted } \\
\text { soybean flour } \\
(\%)\end{array}$ & $\begin{array}{c}\text { Chickpea flour } \\
(\%)\end{array}$ & \multicolumn{3}{|c|}{ Gums (\%) } \\
\cline { 6 - 9 } & & & & Guar & xanthan & CMC \\
\hline 1 & 54.0 & 25 & 10 & 10 & - & - & 1.0 \\
2 & 53.5 & 25 & 10 & 10 & - & - & 1.5 \\
3 & 54.5 & 25 & 10 & 10 & 0.25 & - & 0.25 \\
4 & 54.5 & 25 & 10 & 10 & - & 0.25 & 0.25 \\
\hline
\end{tabular}




\section{Physical properties}

The average weight $(\mathrm{g})$ of cupcake was determined individually within one hour after baking. The volume $\left(\mathrm{cm}^{3}\right)$ of cupcake was determined by TexVol Instruments AB Box 45, 26040 Viken, Sweden. Specific volume was calculated according to the method of (AACC, 2000) using the following equation:

Specific volume $=$ Volume $\left(\mathrm{cm}^{3}\right) /$ Weight $(\mathrm{g})$

\section{Color}

Crust and crumb color were measured using the color profile system of lightness $\left(L^{*}\right)$, redness $\left(a^{*}\right)$ and yellowness $\left(b^{\star}\right)$ which was measured by a reflectance colorimeter (Minolta Spectrophotometer CM-3500d, Japan).

The total $(\Delta \mathrm{E})$ color difference from the control calculated as the following:

$$
\Delta \mathrm{E}=\sqrt{ }\left(\mathrm{L}_{0}{ }^{*}-\mathrm{L}^{*}\right)^{2}+\left(\mathrm{a}_{0}{ }^{*}-\mathrm{a}^{*}\right)^{2}+\left(\mathrm{b}_{0}{ }^{*}-\mathrm{b}^{*}\right)^{2}
$$

Where: $0=$ color reading of control

\section{Alkaline water retention capacity (staling rate)}

Alkaline water retention capacity of cupcake was determined according to the method of Kitterman and Rubentholar (1971). Alkaline water retention capacity of cupcake was determined during storage at room temperature $\left(-25^{\circ} \mathrm{C}\right)$ for 6 days.

\section{Sensory properties}

Sensory properties were carried out by ten-trained panellists who represented graduate students and staff members in the Department of Food science and Technology, Faculty of Agriculture, Menoufia University, Shibin El-Kom, Egypt. Randomly coded samples were served to panellists individually. Six sensory attributes were evaluated (appearance, crust color, crumb color, taste, aroma, and overall acceptability) using nine-points hedonic scale for each trait where $9=$ like extremely, $8=$ like very much, $7=$ like moderately, $6=$ like slightly, $5=$ neither like nor dislike, $4=$ dislike slightly, 3 = dislike moderately, 2 = dislike very much and $1=$ dislike extremely.

\section{Statistical analysis:}

Proximate composition, physical properties and sensory properties data of cupcake were analyzed by one-way analysis of variance. Alkaline water retention capacity data were analyzed by two-ways analysis of variance. An analysis of variance was conducted using Costat version 6.311 (Copyright 1998-2005, CoHort software). When a significant main effect was detected, the means were separated with the Student Newman Keuls test. The predetermined acceptable level of probability was $5 \%$ $(P \leq 0.05)$ for all comparisons.

\section{RESULTS AND DISCUSSION Mixolab profile}

Composite flours had higher water absorption and dough stability than control flour (Table 1) and Fig (1). Usually, increased water absorption and dough stability indicate stronger dough. The increase of water absorption and dough stability of composite flour dough might be due to the presence of hydrocolloids. Similar results were reported by Hegazy et al (2009) for gluten-free bread. The $\mathrm{C} 1$ and $\mathrm{C} 2$ values were not affected by replacing wheat flour with composite flours. Aly-Aldin (2016) reported that $\mathrm{C} 1$ and $\mathrm{C} 2$ values of wheat flour replaced with different levels of flaxseed flour were so close to wheat flour. The C3, C4 and C5 values of wheat flour were higher than composite flours. Iuliana et al. (2008) reported that samples with lower values for C4 and C5 are correlated with higher value of the bread.

\section{Mixolab simulator mode properties}

Composite flours had higher water absorption and dough stability than control flour (Table 2) and Fig (2). These results are supported by the results previously reported in Tables 1. Dough development time and dough weakening values of composite flour 


\section{A. A. A. Hassan, et al.,}

were so close to wheat flour. Hegazy et al. (2009) evidence increase in water absorption, dough development time and dough stability were observed for gluten-free dough as compared with control.

Table (1): Mixolab profiles of wheat flour and composite flours

\begin{tabular}{lccccc}
\hline \multicolumn{1}{c}{ Mixolab properties } & Control & 11 & 2 & 3 & 4 \\
\hline Water absorption (\%) & 55.5 & 56.2 & 56.5 & 57.2 & 57.6 \\
Dough stability (min) & 6.0 & 9.07 & 6.22 & 6.22 & 6.27 \\
C1 (Nm) & 1.12 & 1.08 & 1.12 & 1.10 & 1.09 \\
C2 (Nm) & 0.48 & 0.42 & 0.52 & 0.39 & 0.38 \\
C3 (Nm) & 2.02 & 1.04 & 1.26 & 0.55 & 1.27 \\
C4 (Nm) & 1.64 & 0.99 & 1.19 & 1.01 & 1.03 \\
C5 (Nm) & 2.55 & 1.24 & 1.74 & 1.62 & 1.62 \\
\hline
\end{tabular}

${ }^{1}$ See Table I

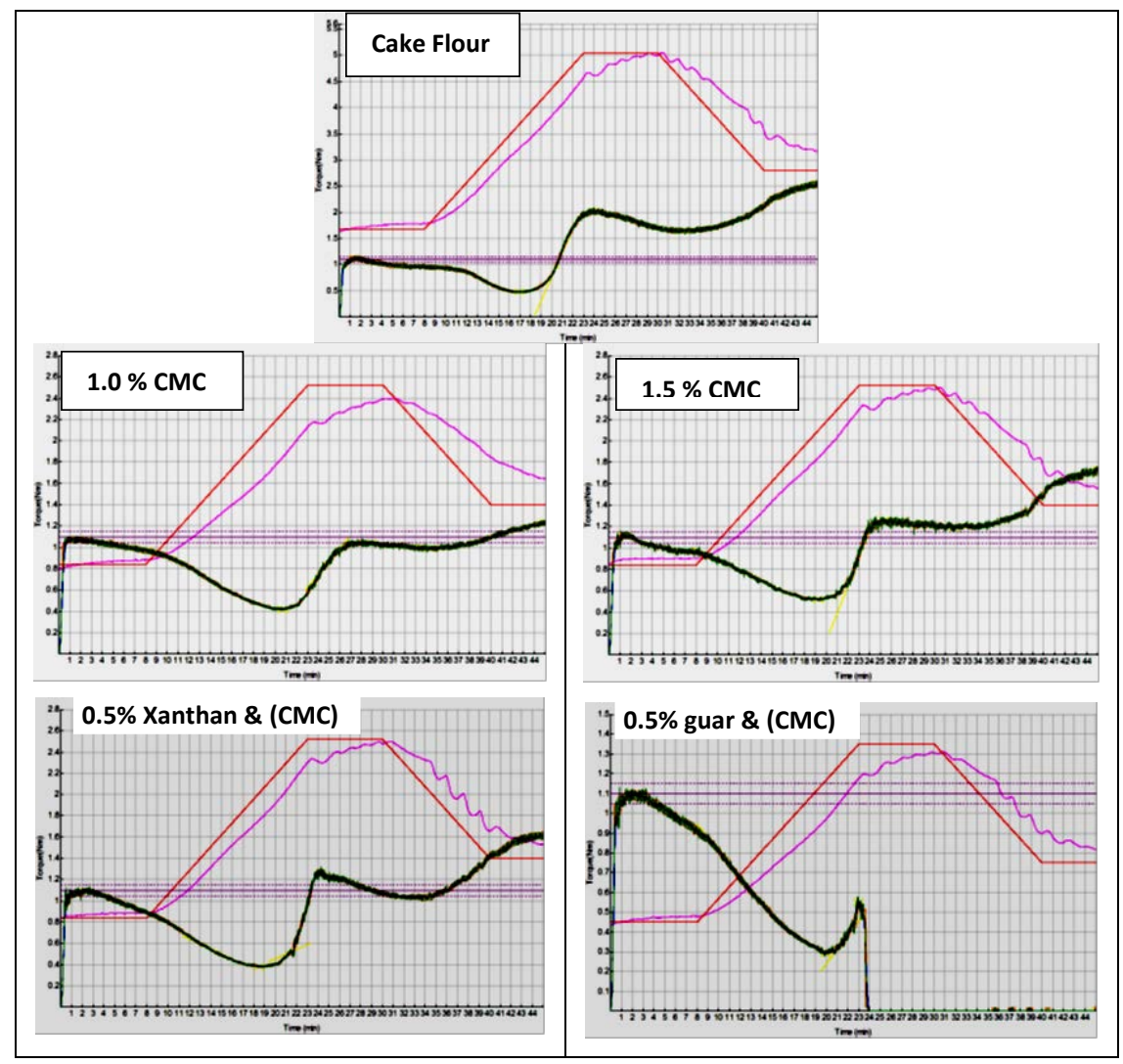

Fig. (1): Mixolab profiles of wheat flour and composite flours 
Effect of gluten -free composite flour on the quality properties of .............

Table (2): Mixolab simulator mode properties of wheat flour and composite flours

\begin{tabular}{llllll}
\hline & Control & ${ }^{1} 1$ & 2 & 3 & 4
\end{tabular}

Mixolab simulator mode properties

\begin{tabular}{lccccc}
\hline Water absorption (\%) & 56.0 & 57.9 & 58.7 & 58.9 & 59.0 \\
Dough development time (min) & 2.5 & 2.5 & 3.0 & 3.0 & 2.5 \\
Dough stability $(\mathrm{min})$ & 1.5 & 6.5 & 7.5 & 4.0 & 5.5 \\
Dough weakening $(\mathrm{Nm})$ & 0.15 & 0.16 & 0.17 & 0.22 & 0.24 \\
\hline
\end{tabular}

1See Table I

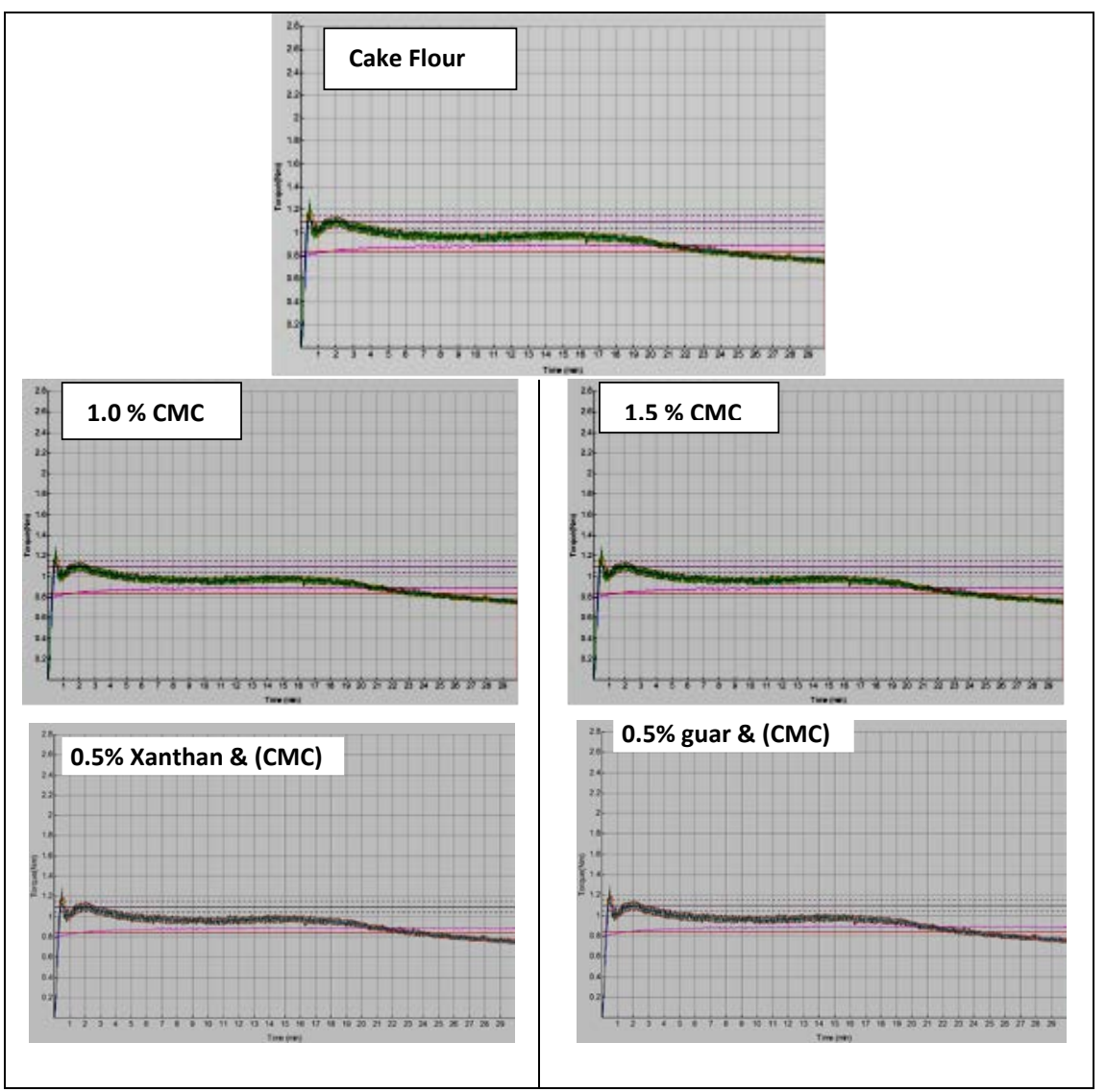

Fig. (2) Mixolab simulator mode properties of wheat flour and composite flours

\section{Proximate composition:}

There were no significantly $(p>0.05)$ differences in moisture and crude fat contents among all cupcakes (Table 3 ). Composite flour cupcakes had higher $(p \leq$ 0.05 ) crude protein and total ash contents than control cupcake. However, control cupcake had higher $(p \leq 0.05)$ carbohydrates content than composite flour cupcakes. In general non-significant $(p>$
0.05) difference in proximate composition was observed among composite flour cupcakes. These results are in agreement with those reported by Faheid and Hegazy (1991) who used soybean flour, chickpea flour and lupine flour to replace wheat flour in cookies. Results indicated that protein and ash contents of supplemented cookies were higher than of control. 
A. A. A. Hassan, et al.,

Table (3): Proximate composition of cupcake prepared from wheat flour and composite flours

\begin{tabular}{lccccc}
\hline Treatment & ${ }^{1}$ Moisture & $\begin{array}{c}\text { Crude } \\
\text { protein } \\
(\%)\end{array}$ & $\begin{array}{c}\text { Crude fat } \\
(\%)\end{array}$ & $\begin{array}{c}\text { Total ash } \\
(\%)\end{array}$ & $\begin{array}{c}\text { Carbohydrates } \\
(\%)\end{array}$ \\
\hline Wheat flour & $19.31^{\mathrm{a}} \pm 0.11$ & $4.32^{\mathrm{b}} \pm 0.09$ & $30.99^{\mathrm{a}} \pm 0.12$ & $0.60^{\mathrm{c}} \pm 0.02$ & $64.09^{\mathrm{a}} \pm 0.16$ \\
21 & $18.40^{\mathrm{a}} \pm 0.40$ & $5.26^{\mathrm{a}} \pm 0.17$ & $30.74^{\mathrm{a}} \pm 0.27$ & $1.01^{\mathrm{a}} \pm 0.02$ & $62.99^{\mathrm{b}} \pm 0.14$ \\
2 & $18.94^{\mathrm{a}} \pm 0.12$ & $5.23^{\mathrm{a}} \pm 0.11$ & $30.73^{\mathrm{a}} \pm 0.50$ & $0.88^{\mathrm{b}} \pm 0.05$ & $63.16^{\mathrm{b}} \pm 0.64$ \\
3 & $19.22^{\mathrm{a}} \pm 0.22$ & $5.26^{\mathrm{a}} \pm 0.15$ & $30.74^{\mathrm{a}} \pm 0.26$ & $1.01^{\mathrm{a}} \pm 0.03$ & $62.99^{\mathrm{b}} \pm 0.11$ \\
4 & $19.42^{\mathrm{a}} \pm 0.12$ & $5.27^{\mathrm{a}} \pm 0.11$ & $30.77^{\mathrm{a}} \pm 0.27$ & $0.88^{\mathrm{b}} \pm 0.03$ & $63.08^{\mathrm{b}} \pm 0.43$ \\
LSD & 0.93 & 0.23 & 0.56 & 0.06 & 0.65 \\
\hline
\end{tabular}

${ }^{1}$ Means in the same column with different letters are significantly different $(p \leq 0.05)$

${ }^{2}$ See Table I

\section{Physical properties}

Non-significant $(p>0.05)$ difference in weight was observed between composite flour cupcakes and control cupcake (Table 4). Composite flour cupcakes containing $1.5 \%$ CMC $\left(1385.3 \mathrm{~cm}^{3}\right)$ followed by containing $1 \% \mathrm{CMC}\left(1355.6 \mathrm{~cm}^{3}\right)$ had higher $(p \leq 0.05)$ volume than other cupcakes. Control cupcake had higher $(p \leq 0.05)$ volume $\left(1276.7 \mathrm{~cm}^{3}\right)$ than composite flour cupcake containing $0.25 \%$ xanthan $+0.25 \%$ CMC (1219.6 $\left.\mathrm{cm}^{3}\right)$ and composite flour cupcake containing $0.25 \%$ gaur gum + $0.25 \%$ CMC $\left(1165.2 \mathrm{~cm}^{3}\right)$. The specific volume of cake (relates with good texture) indicates the amount of air that can remain in the final product. A higher gas retention and higher expansion of the product leads to a higher specific volume (Gomez et al., 2008). Specific volumes of composite flour cupcakes containing 1\% CMC (2.16) and 1.5\% CMC (2.20) were significantly ( $p \leq$ $0.05)$ higher than control (2.02) and composite flour cupcakes containing $0.25 \%$ xanthan + 0.25\% CMC (1.94) and 0.25\% gaur gum $+0.25 \%$ CMC (1.86). Control cupcake had higher $(p \leq 0.05)$ specific volume than composite flour cupcakes containing $0.25 \%$ xanthan $+0.25 \%$ CMC and $0.25 \%$ gaur gum $+0.25 \%$ CMC. Height of cupcakes had a similar trend of specific volume. Yaseen et al. (2010) reported that loaf volume and specific volume were improved upon the addition of gums arabic and pectin.

\section{Crust color}

In general, a lower $L^{*}$ value indicates a darker crust, $a^{*}$ positive value is associated with crust redness, whereas a higher $b^{*}$ value leads to higher crust yellowness. Composite flour containing $0.25 \%$ gaur gum $+0.25 \%$ CMC had the highest crust lightness (69.14), yellowness (37.02) and $\Delta \mathrm{E}$ (11.59) and the lowest redness (10.54) as compared with other cupcakes (Table 5). Control cupcake had the lowest lightness (58.0) and the highest redness (13.47) among all cupcakes. In general, composite flour cupcakes had lighter crust color than control cupcake. This could be attributable to the effect of hydrocolloids on water distribution, which impact on maillard reaction and caramelization. Mezaize et al. (2009) reported that breads made with xanthan gum and CMC had lighter crust color. 
Effect of gluten -free composite flour on the quality properties of .............

Table (4): Physical properties of cupcake prepared from wheat flour and composite flours

\begin{tabular}{lcccc}
\hline Treatment & $\begin{array}{c}1 \text { Weight } \\
(\mathrm{g})\end{array}$ & $\begin{array}{c}\text { Volume } \\
\left(\mathrm{cm}^{3}\right)\end{array}$ & $\begin{array}{c}\text { Specific } \\
\text { volume } \\
\left(\mathrm{cm}^{3} / \mathrm{g}\right)\end{array}$ & $\begin{array}{c}\text { Height } \\
(\mathrm{cm})\end{array}$ \\
\hline Wheat flour & $632.03^{\mathrm{a}} \pm 11$ & $1276.70^{\mathrm{c}} \pm 24$ & $2.02^{\mathrm{b}} \pm 0.08$ & $4.00^{\mathrm{b}} \pm 0.15$ \\
${ }^{2} 1$ & $627.60^{\mathrm{a}} \pm 12$ & $1355.60^{\mathrm{b}} \pm 31$ & $2.16^{\mathrm{a}} \pm 0.09$ & $4.15^{\mathrm{a}} \pm 0.15$ \\
2 & $630.60^{\mathrm{a}} \pm 11$ & $1385.30^{\mathrm{a}} \pm 33$ & $2.20^{\mathrm{a}} \pm 0.10$ & $4.22^{\mathrm{a}} \pm 0.12$ \\
3 & $628.40^{\mathrm{a}} \pm 12$ & $1219.60^{\mathrm{d}} \pm 22$ & $1.94^{\mathrm{c}} \pm 0.07$ & $3.30^{\mathrm{c}} \pm 0.11$ \\
4 & $625.50^{\mathrm{a}} \pm 13$ & $1165.20^{\mathrm{e}} \pm 19$ & $1.86^{\mathrm{d}} \pm 0.07$ & $3.40^{\mathrm{c}} \pm 0.09$ \\
LSD & 7.22 & 19.37 & 0.06 & 0.13
\end{tabular}

${ }^{1}$ Means in the same column with different letters are significantly different $(p \leq 0.05)$

${ }^{2}$ See Table I

Table (5): Crust color of cupcake prepared from wheat flour and composite flours

\begin{tabular}{lcccc}
\hline Treatment & $\mathrm{L}^{*}$ & $\mathrm{a}^{*}$ & \multicolumn{1}{c}{$\mathrm{b}^{*}$} & $\Delta \mathrm{E}$ \\
\hline Wheat flour & 58.00 & 13.47 & 35.72 & 0.00 \\
${ }^{1} 1$ & 68.40 & 11.30 & 34.00 & 10.76 \\
2 & 67.48 & 11.34 & 33.00 & 9.69 \\
3 & 65.73 & 13.20 & 36.92 & 7.83 \\
4 & 69.14 & 10.54 & 37.02 & 11.59 \\
\hline
\end{tabular}

1See Table I

\section{Crumb color}

Composite flour cupcake containing $1.5 \%$ CMC had the highest crumb redness (1.91) and $\Delta \mathrm{E}(6.61)$ and the lowest lightness (74.62) and yellowness (23.86) as compared with other cupcakes (Table 6). This indicated that composite flour cupcake containing 1.5\% CMC had the darker crumb color among all cupcakes. This might be due to the increase of $\mathrm{CMC}$ ratio $(1.5 \%)$ in the sample. Sciarini et al. (2010) found that a darkening of the bread crust color with carrageenan addition. The other composite flour cupcakes had lighter crumb color than the control cupcake and composite flour containing $1.5 \% \mathrm{CMC}$.

\begin{abstract}
Alkaline water retention capacity
Water retention capacity of cupcakes was significantly $(p \leq 0.05)$ affected by the type of flours and storage period (Table 7). Alkaline water retention capacity of composite flours cupcakes was significantly $(p \leq 0.05)$ lower than control cupcake. Alkaline water retention capacity of cupcake was significantly $(p \leq 0.05)$ decreased by increasing storage period. These results are in agreement with those reported by AlyAldin (2016) for flat bread prepared by replacing wheat flour with different levels of germinated flaxseed flour.
\end{abstract}


A. A. A. Hassan, et al.,

Table (6): Crumb color of cupcake prepared from wheat flour (72 extraction) and composite flours

\begin{tabular}{lcccc}
\hline Treatment & $\mathrm{L}^{*}$ & $\mathrm{a}^{*}$ & $\mathrm{~b}^{*}$ & $\Delta \mathrm{E}$ \\
\hline Wheat flour & 75.92 & -0.66 & 29.81 & - \\
${ }^{1} 1$ & 78.00 & 1.00 & 27.30 & 3.66 \\
2 & 74.62 & 1.91 & 23.86 & 6.61 \\
3 & 80.28 & -1.15 & 30.50 & 4.40 \\
4 & 80.28 & -0.98 & 28.93 & 4.46
\end{tabular}

${ }^{1}$ See Table I

Table (7): Alkaline water retention capacity of cupcake prepared from wheat flour (72 extraction) and composite flours during storage at room temperature $\left(\sim 25^{\circ} \mathrm{C}\right)$ for 6 days.

\begin{tabular}{lccccc}
\hline \multirow{2}{*}{ Treatment } & \multicolumn{4}{c}{ Storage period (day) } & \multirow{2}{*}{ Means $^{1}$} \\
\cline { 2 - 5 } & 0 & ${ }^{3} 1$ & 3 & 6 & \\
\hline Wheat flour & $261.14 \pm 0.24$ & $255.27 \pm 0.94$ & $255.18 \pm 0.40$ & $252.58 \pm 0.42$ & $256.05^{\mathrm{a}}$ \\
1 & $223.54 \pm 0.54$ & $214.91 \pm 0.09$ & $210.74 \pm 0.26$ & $199.19 \pm 0.30$ & $212.10^{\mathrm{a}}$ \\
2 & $224.95 \pm 0.95$ & $218.31 \pm 0.41$ & $214.23 \pm 0.30$ & $200.32 \pm 0.39$ & $214.45^{\mathrm{d}}$ \\
3 & $232.24 \pm 0.76$ & $226.91 \pm 0.91$ & $218.27 \pm 0.32$ & $202.51 \pm 0.61$ & $222.45^{\mathrm{b}}$ \\
4 & $231.99 \pm 1.01$ & $225.70 \pm 0.75$ & $221.85 \pm 0.50$ & $210.25 \pm 0.70$ & $219.93^{\mathrm{c}}$ \\
Means $^{2}$ & $234.77^{\mathrm{a}}$ & $228.22^{\mathrm{b}}$ & $224.06^{\mathrm{c}}$ & $212.90^{\mathrm{d}}$ & \\
\hline
\end{tabular}

${ }^{1}$ Means in the same column with different letters are significantly different ( $\left.p \leq 0.05\right)$, LSD 0.51

${ }^{2}$ Means in the same row with different letters are significantly different $(p \leq 0.05)$, LSD $=0.46$

${ }^{3}$ See Table I

\section{Sensory properties}

Control cupcake had higher $(p \leq 0.05)$ rating scores of all sensory properties than composite flour cupcake (Table 8). Control cupcake had higher $(p \leq 0.05)$ rating scores of appearance, crumb color, crust color, taste and aroma than composite flour cupcakes. Non-significant $(p>0.05)$ differences in appearance and crumb color were observed between control cupcake and composite flour cupcakes containing $1.5 \% \mathrm{CMC}$ and $0.25 \%$ gaur gum $+0.25 \%$ CMC. Non-significant $(p>0.05)$ difference in overall acceptability was observed between control cupcake and composite flour cupcakes containing 1.5\% CMC, $0.25 \%$ xanthan $+0.25 \% \mathrm{CMC}$ and $0.25 \%$ gaur gum $+0.25 \%$ CMC. Overall acceptability of control cupcake had rating score described as like extremely. However, composite flour cupcakes containing 1.5\% CMC, $0.25 \%$ xanthan $+0.25 \% \mathrm{CMC}$ and $0.25 \%$ gaur gum $+0.25 \%$ CMC had rating score described as like very much. Although composite flour cupcake containing $1 \%$ CMC had lower $(p \leq$ $0.05)$ sensory properties than control cupcake, it had rating scores described as like slightly. Ranjbar et al. (2012) reported that rice cakes containing $\mathrm{CMC}$ had better sensory properties than control rice cake. 
Table (8): Sensory properties of cupcake prepared from wheat flour and composite flours

\begin{tabular}{lcccccc} 
Treatment & Appearance & $\begin{array}{c}\text { Crust } \\
\text { color }\end{array}$ & $\begin{array}{c}\text { Crumb } \\
\text { color }\end{array}$ & Taste & Aroma & $\begin{array}{c}\text { Overall } \\
\text { acceptability }\end{array}$ \\
\hline Wheat flour & $9.00^{\mathrm{a}}$ & $9.00^{\mathrm{a}}$ & $9.00^{\mathrm{a}}$ & $9.00^{\mathrm{a}}$ & $9.00^{\mathrm{a}}$ & $9.00^{\mathrm{a}}$ \\
& \pm 0.03 & \pm 0.03 & \pm 0.03 & \pm 0.03 & \pm 0.03 & \pm 0.03 \\
${ }^{1} 1$ & $6.00^{\mathrm{cd}}$ & $6.00^{\mathrm{c}}$ & $6.00^{\mathrm{b}}$ & $6.00^{\text {cd }}$ & $6.00^{\mathrm{cd}}$ & $6.00^{\mathrm{b}}$ \\
& \pm 0.50 & \pm 0.50 & \pm 0.50 & \pm 0.50 & \pm 0.50 & \pm 0.50 \\
2 & $8.00^{\mathrm{ab}}$ & $7.50^{\mathrm{b}}$ & $8.00^{\mathrm{ab}}$ & $8.00^{\mathrm{b}}$ & $7.75^{\mathrm{b}}$ & $8.00^{\mathrm{a}}$ \\
& \pm 0.05 & \pm 0.57 & \pm 0.10 & \pm 0.50 & \pm 0.50 & \pm 0.10 \\
3 & $7.00^{\mathrm{bc}}$ & $8.00^{\mathrm{b}}$ & $7.25^{\mathrm{b}}$ & $7.50^{\mathrm{b}}$ & $7.25^{\mathrm{bc}}$ & $8.00^{\mathrm{a}}$ \\
& \pm 0.10 & \pm 0.50 & \pm 0.95 & \pm 0.57 & \pm 0.95 & \pm 0.50 \\
& $8.00^{\mathrm{ab}}$ & $7.50^{\mathrm{b}}$ & $7.75^{\mathrm{ab}}$ & $7.00^{\mathrm{bc}}$ & $7.75^{\mathrm{b}}$ & $8.00^{\mathrm{a}}$ \\
& \pm 0.50 & \pm 0.57 & \pm 0.10 & \pm 0.80 & \pm 0.50 & \pm 0.50 \\
\hline \multirow{2}{*}{ LSD } & 1.09 & 0.80 & 1.27 & 0.89 & 0.87 & 1.0 \\
\hline
\end{tabular}

Means in the same column with different letters are significantly different $(p \leq 0.05)$

${ }^{1}$ See Table I

\section{CONCLUSION}

Composite flours had higher water absorption and dough stability than control flour. Dough development time, dough weakening, C1 and C2 values did not differ among all cupcakes. Composite flour dough had lower C3, C4 and C5 values than wheat flour dough. Composite flour cupcakes had higher crude protein and total ash contents and lower carbohydrates content than control cupcake. Specific volumes of composite flour cupcakes containing 1 and $1.5 \%$ CMC were higher than control cupcake and other composite flour cupcakes. Composite flour cupcakes had lighter crust color and crumb color than control cupcake except for composite flour cupcake containing 1.5\% CMC which had the darker crumb color among all cupcakes. Composite flour cupcakes had lower alkaline water retention capacity than control cupcake. Alkaline water retention capacity of cupcakes was decreased by increasing storage period. There was no difference in overall acceptability between control cupcake and composite flour cupcakes containing $1.5 \% \mathrm{CMC}, 0.25$ xanthan +
$0.25 \%$ CMC and $0.25 \%$ guar gum +0.25 CMC. Therefore, it is possible to produce cupcake of high and good quality properties from composite flour free of gluten.

\section{REFERENCES}

AACC (2000). Approved Methods of the American Association of Cereal Chemists. American Association of Cereal Chemists, St Paul, MN.

Alvarez-Jubete, L., M. Auty, E.K. Arendt and E. Gallagher (2010). Baking properties and microstructure of pseudocereal flours in gluten-free bread formulations. Eur Food Res Technol 230:437-445

Aly-Aldin, M. M. (2016). Chemical, Technological and Nutritional Studies on Flaxseeds. Ph.D. Thesis, Food Science and Technology Dept., Fac. of Agric., Menoufia Univ. Egypt.

AOAC (2005). Official Methods of Analysis, $18^{\text {th }}$ ed. Association of Official Analytical Chemists, Washington, USA.

Correa, M.J., M.C. Añón, G.T. Pe'rez and C. Ferrero (2010). Effect of modified celluloses on dough rheology and microstructure. Food Res Int 43:780-787 
Faheid, Siham M.M. and Nefisa A. Hegazi (1991). Effect of adding some legume flours on the nutritive value of cookies. Egypt. J. Food Sci., 19, 147-159.

Gallagher, E., Gormley, T. R., and Arendt, E. K. (2004). Recent advances in the formulation of gluten-free cereal-based products. Trends in Food Science and Technology, 15, 143-152.

Gessendorfer, B., H. Wieser and P. Koehler (2010). Optimisation of a solvent for the complete extraction of prolamins from heated foods. Journal of Cereal Science, 52, 331-332.

Gomez, M., B. Oliete, C.M. Rosell, V. Pando and E. Fern॰ndez (2008). Studies on cake quality made of wheat-chickpea flour blends. LWT Food Sci. Technol., 41: 1701-1709.

Hegazy, A.I., M.S. Ammar and M.I. Ibrahium (2009). Production of Egyptian glutenfree bread. World Journal of Dairy \& Food Sciences 4 (2): 123-128

Hussein, A.M.S., N.A. Hegazy and T.A.A. Ibrahim (2012). Production and evaluation of gluten-free cakes Australian Journal of Basic and Applied Sciences, 6(12): 482-491

Iuliana, B., S. Georgeta and I. Violeta (2008). Improvement of dough rheology and bread quality by enzymes combination bulletin UASVM, Agriculture World Journal of Dairy \& Food Sciences 4 (2): 123-128

Khalil, A. H. (1998). The influence of carbohydrate-based fat replacers with and without emulsifiers on the quality characteristics of low fat cake. Plant Foods for Human Nutrition, 52: 299 313.

Kitterman, J.S. and G.L. Rubenthalor (1971). Assessing the quality of early generation wheat selection with micro AWRC test. Cereal Sci. Today, 16: 313316.

Kotoki D. and S.C. Deka (2010). Baking loss of bread with special emphasis on increasing water holding capacity. J. Food Sci., Technol 47(1):128-131
Larre, C., R. Lupi, R. Gombaud, G. Brossard, C. Branlard, G. MoneretVautrin, D. A. Rogniaux and H. DeneryPapini (2011). Assesment of allergenicity of diploid and hexaploid wheat genotypes: Identification of allergens in the albumin/globulin fraction. Journal of Proteomics, 74, 1279-1289.

Lohi, S., K. Mustalahti, K. Kaukinen, K. Laurila, P. Collin, H. Rissanen, O. Lohi, E. Bravi, M. Gasparin, A. Reunanen and M. Ma"ki (2007). Increasing prevalence of coeliac disease over time. Aliment Pharmacol Ther 26(9):1217-1225

Mezaize, S., S. Chevallier, A. Le Bail and M. Lamballerie (2009). Optimization of gluten-free formulations for french-style breads. J Food Sci 74(3):E140-E146

Moore, M. M., M. Heinbockel, P. Dockery, H. E. Ulmer and E. K. Arendt (2006). Network formation in gluten-free bread with application of transglutaminase. Cereal Chemistry, 83(1), 28-36.

Ranhotra, G.S., R.J. Loewe and I.V. Puyat (1975). Preparation and evaluation of soy-fortified gluten-Free bread. Journal of Food Science, 40, 62-64.

Ranjbar, S., S. Movahhed, N. Nematti and R. Sokotifar (2012). Evaluation of the effect of carboxy methyl cellulose on sensory properties of gluten-free cake. Research Journal of Applied Sciences, Engineering and Technology 4(19): 3819-3821.

Sanchez, H.D., C.A. Osella and M.A. de la Torre (2004). Use of response surface methodology to optimize gluten-free bread fortified with soy flour and dry milk. Food Sci. Technol. Intl., 10: 5-9.

Sciarini, L.S., P.D. Ribotta, A.E. León and G.T. Pérez (2010). Influence of glutenfree flours and their mixtures on batter properties and bread quality. Food Bioprocess Technol 3:577-585.

Yaseen, A.A., A.A. Shouk and M.T. Ramadan (2010). Corn-wheat pan bread quality as affected by hydrocolloids. J. Amer. Sci., 6, 684-690. 


\section{تأثير الاقيق المركب خالي الجلوتين علي خواص وجودة الكيك}

أمل أحمد عاطف حسن ، الفتحى ابو بكر البركولى ، على حسن خليل ، عصام الدين حافظ منصور ،

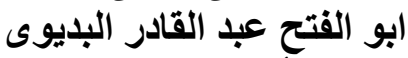

قسم علوم وتكنولوجيا الأغذية ، كلية الزر اعة، جامعة المنوفية الئوى

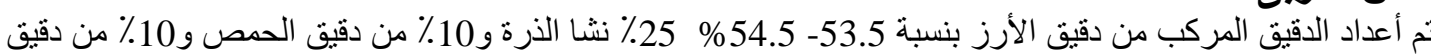

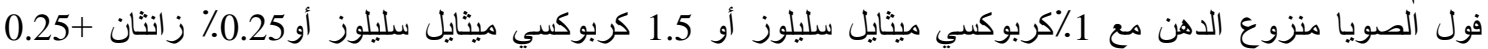

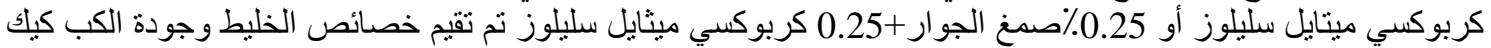

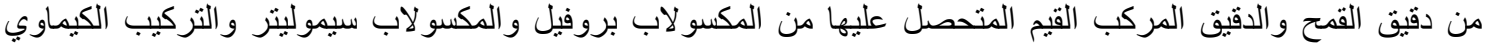

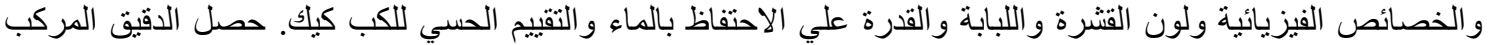

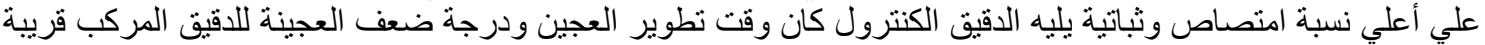

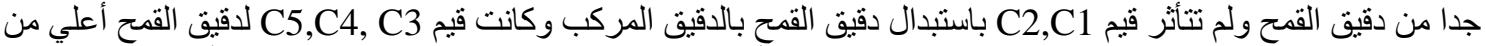

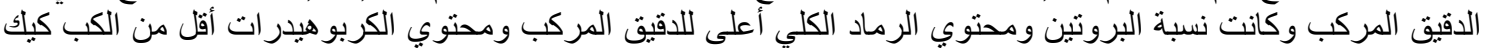

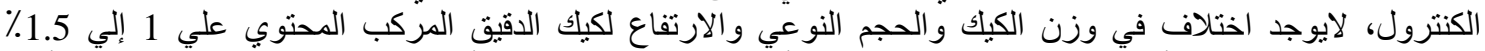

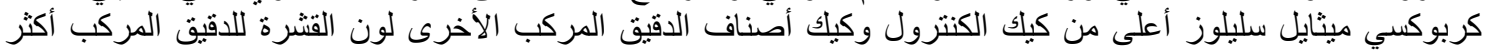

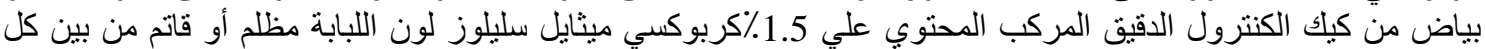

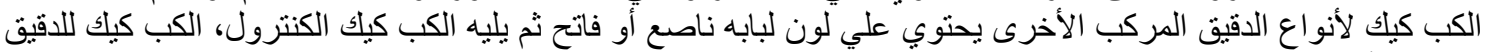

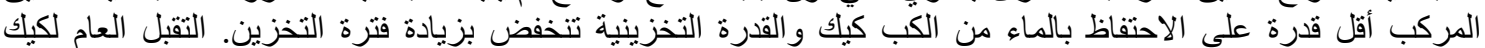

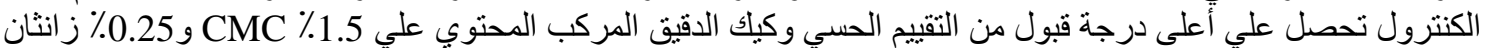

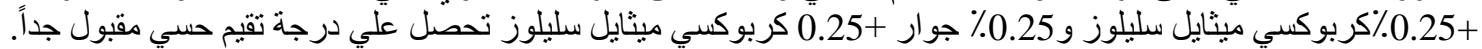
الكلمات الدالة (key words): مكسو لاب بروفيل و المكسو لاب سيموليتر، لون القشرة و اللبابة القدرة علي الاحتفاظ بالماء 